УДК 159.9

\title{
ПЕСОЧНАЯ ТЕРАПИЯ КАК СРЕДСТВО РАЗВИТИЯ ЭМОЦИОНАЛЬНОЙ СФЕРЫ МЛАДШИХ ШКОЛЬНИКОВ
}

\author{
Красавина Надежда Сергеевна \\ ГБОУ СОШ № 436
}

\begin{abstract}
Аннотация: В данной статье отражено описание песочной терапии как средства развития эмоциональной сферы детей младшего школьного возраста. Приводится фрагмент занятия с использованием данной техники с целью коррекции и развития эмоциональной сферы первоклассника, имеющего нарушения в поведении и в межличностном общении.

Ключевые слова: младшие школьники, эмоциональная сфера, песочная терапия, коррекция, эмоциональный фон.

\section{SANDPLAY AS A MEANS OF DEVELOPING THE EMOTIONAL SPHERE OF A PRIMARY SCHOOLCHILDREN}

Krasavina Nadezhda Sergeevna

\begin{abstract}
This article describes the description of sand therapy as a means of developing the emotional sphere of primary school children. A fragment of a lesson using this technique is given in order to correct and develop the emotional sphere of a first-grader who has a behavior disorder and interpersonal communication.

Key words: primary school children, emotional sphere, sand therapy, correction, emotional background.

В последние годы в системе обучения стала прослеживаться тенденция к интеллектуальному развитию ребёнка. При этом развитию эмоциональной сферы часто уделяется недостаточное внимание. На современном этапе развития науки и образования особо актуальным является использование нестандартных подходов в работе с детьми. Во многих образовательных организациях существует вариативность форм и методов в работе с младшими школьниками, позволяющая влиять на их гармоничное развитие эмоциональной сферы. К одному из таких методов можно отнести песочную
\end{abstract}


терапию, представляющую собой один из видов арт-терапии, обеспечивающих развитие положительных эмоций у детей.

По традиции ведущей формой работы в практической деятельности педагога-психолога является вербальная коммуникация. Однако нередко она бывает неэффективной в работе с детьми, которые затрудняются в вербальном выражении своих переживаний. Песочная терапия представляет собой одну из продуктивных техник коррекционно-развивающего процесса, во время которого ребенок строит собственный мир из песка и миниатюрных фигурок.

Психотерапевтическая работа с песком начала использоваться в конце 20-х годов прошлого века. Теоретической основой терапии была техника активного воображения, разработанная К. Юнгом. Картины из песка, создаваемые в песочнице, возвращали человека в детство и активизировали «архетип ребенка», позволяя вести эффективную работу с ним [1, с. 273].

В трудах В.М. Бехтерева, И.М. Сеченова описана концепция творческого рационального подхода, исходя из которого, терапевтические воздействия (включая песочную терапию) стимулируют не только физиологические, но и эмоциональные ресурсы личности ребенка. Оклендер В. отмечал, что диагностические процедуры песочной терапии базируются на признании бессознательного и того, что образы являются его естественным «языком» [2, с. 136]. А В.Н. Мясищев считал, что песочная терапия делает ребенка не только объектом, но и субъектом реабилитационного процесса $[3$, c. 116$]$.

Особый вклад в развитие песочной терапии внесли педагоги СанктПетербургского Института специальной педагогики и психологии Грабенко Т.М., Зинкевич-Евстигнеева Т.Д., являющиеся авторами ряда книг по данной теме. Ученые отмечали, что песочная терапия может использоваться в современных школах как эффективный метод в работе с детьми, поскольку продукты песочного творчества - это объективные показатели актуальных настроений, мыслей человека, позволяющие наблюдать динамику состояний ребенка. Общение через символы на песке позволяет ребенку точнее выразить свои переживания, иначе взглянуть на ситуацию, проблемы, найти пути их решения [4, с. 16].

Однако, несмотря на актуальность и достаточную изученность вопроса использования песочной терапии в работе с детьми, в настоящее время наблюдается дефицит ее применения педагогами-психологами образовательных организаций. Это связано, как с недостаточным 
материальным оснащением развивающей пространственной образовательной среды, так и с отсутствием у специалистов опыта использования технологии.

Рассмотрим план индивидуальной работы на тему «Построение мира «Моя семья»»», используемой для коррекции и развития эмоциональной сферы первоклассника, имеющего нарушение в поведении и в межличностном общении. Занятие входит в цикл консультативной работы.

Задачами проведения занятия являются:

- создание у ребенка положительного эмоционального настроя с помощью применения методов песочной терапии;

- стабилизация эмоционального фона обучающихся с помощью песочной техники;

- диагностика и коррекция семейных отношений при помощи песочной терапии.

Материал: Песочница, фигурки людей и животных, дома.

Фрагмент занятия.

Для начала необходимо вспомнить правила обращения с песком. Ребенок перечисляет вслух:

- Нельзя сыпать песок на пол;

- Нельзя тереть глаза руками, когда работаешь,

- Нельзя брать песок в рот;

Работать нужно аккуратно.

\section{Игра «Отпечатки»}

На ровной поверхности песка ребенок и психолог по очереди отставляют отпечатки рук: внутренней и внешней стороной. Взрослый начинает игру, рассказывая ребенку о своих ощущениях: «Мне приятно. Я чувствую прохладу песка. Когда я перемещаю руки, я ощущаю маленькие песчинки. А что чувствуешь ты?» Ребенок получает образец проговаривания и попробует сам рассказать, что ощущает.

Далее психолог переворачивает руки ладонями вверх: «Я перевернула руки и мои ощущения изменились. Теперь я по-другому чувствую шероховатость песка. Мне не очень удобно. А тебе?» Если у ребенка похожие ощущения, можно обсудить: что лучше сделать, чтобы их изменить.

Варианты работы с песком:

- «поскользить» ладонями по поверхности песка, выполняя зигзагообразные и круговые движения (как машинки, змейки, санки и др.) 
- выполнить те же движения, поставив ладонь на ребро;

- «пройтись» ладошками по песку, оставляя на нем следы;

- создать отпечатками кулачков или костяшками кистей рук узоры на поверхности песка, попытаться найти сходство узоров с объектами окружающего мира (солнышко, травки, дерева и пр.);

- группировать пальцы по два, по три, по четыре, по пять. Пофантазировать: чьи следы получились.

Физкультминутка. («Близкие» пальчики)

Психолог: кто у нас самые близкие друзья, которые нас любят, заботятся о нас? Ответ ребенка подвести к значимости семьи.

Психолог: Что они для нас делают? Ответ ребенка.

Сегодня на занятии нужно рассказать о своей семье при помощи волшебного песка. Ты можешь нужные фигурки людей, но может быть, кто-то из твоих родных напоминает какое-то животное или цветок, такую фигурку тоже можно взять. Это может быть животное, птица, сказочный персонаж и т.д., и представить, что эти фигурки они сами, затем назвать своего героя, рассказать, почему именно выбрал этого персонажа, придумать чем он занимается.

После этого психолог предлагает построить на песке общий дом так, чтобы у каждого героя было свое место и занятие, после чего психолог спрашивает у ребенка, с кем дружит тот или иной герой.

Построение идет под тихую медленную музыку.

После построения мира, ребенок рассказывает о семье.

\section{Рефлексия занятия.}

Чем мы занимались сегодня на занятии? Что было наиболее приятным?

Ритуал «выхода» из Песочной страныл.

Педагог приглашает ребенка помыть руки и убрать свое рабочее место.

Таким образом, использование на занятиях кинетического песка в коррекционной работе с детьми может дать положительную эффективность применения. Песочная терапия в работе педагога-психолога будет полезным дополнением на коррекционно-развивающих занятиях, если у ребенка наблюдаются проблемы в эмоциональной сфере. 


\section{Список литературы}

1. Юнг К.Г. Человек и его символы / К.Г. Юнг. - М.: Серебряные нити, 2013. $-352 \mathrm{c}$.

2. Оклендер, В. Окна в мир ребенка. Руководство по детской психотерапии / В. Оклендер. - М.: Независимая фирма Класс, 2015. - 336 с.

3. Стрельцова В.П. Психологические воззрения В.Н. Мясищева / В.П. Стрельцова. - Тверь: Из-во «СФК-офис», 2009. - 288 с.

4. Грабенко Т.М., Зинкевич-Евстигнеева Т. Д. Чудеса на песке. Песочная игротерапия. - СПб.: Институт специальной педагогики и психологии, 1998. -50 с.

(C) Красавина Н.С, 2021 